\title{
Core Skills Requirement and Competencies Expected of Quantity Surveyors: Perspectives from Quantity Surveyors, Allied Professionals and Clients in Nigeria
}

\author{
Joshua Oluwasuji Dada, (Obafermi Awolowo University, Nigeria) \\ Godwin Onajite Jagboro, (Obafermi Awolowo University, Nigeria)
}

\begin{abstract}
Deployment of appropriate skills and competencies is crucial and germane to the development and continuous relevance of any profession. In the built environment, the art of selecting the required skills and competencies expected of quantity surveyors and understanding the inherent dependencies between them remains a research issue. The purpose of this study was to determine the skill requirements and competencies expected of quantity surveyors. A structured questionnaire was administered among quantity surveyors, architects, engineers, builders and clients in Nigeria. The respondents were asked to give rating, on a 5 point Likert scale, on usual skills and competencies required of quantity surveyors. A secondary objective of the study was to examine the important skills and competencies and categorized them into core skill, basic skill, core competence, optional competence and special competence. The results of the study indicate the important skills as computer literacy, building engineering, information technology, economics, measurement/quantification and knowledge of civil/heavy engineering works. The results also indicate the important competencies to be cost planning and control, estimating, construction procurement system, contract documentation, contract administration and project management. The findings of the research have considerable implications on the training and practice of quantity surveying in Nigeria.
\end{abstract}

Keywords: Skill, competence, quantity surveyors, Nigeria

\section{Introduction}

Quantity surveyors add value primarily to the financial and contractual management of construction projects at the pre-construction, construction and post construction stages. They contribute to overall construction project performance by acquiring, developing and deploying appropriate competencies (Nkado and Meyer, 2001). The profession of quantity surveying is practiced in Nigeria along the same pattern as in the United Kingdom and other commonwealth countries. The Regulated and Other Professions (Miscellaneous Provisions) Act 1978 of Nigeria recognized Quantity Surveying profession as one of the scheduled Professions while Decree No. 31 of 1986 gave legal backing to the profession and also set up the Quantity Surveying Registration Board of Nigeria (QSRBN) to regulate it.

In the evaluation of the training needs of construction site managers, Odusami et al. (2007) opined that the general belief in modern times is that construction site managers are being faced with skill shortages. How they have been coping with the dynamism of the changing world of construction technology, materials innovation, management techniques, knowledge profusion and client requirement remains a subject of continuous inquiry. While this submission may not be different from the performance expectation of quantity surveyors; investigation into their competencies has been of interest to researchers in quantity surveying training and practice.

Skill can be defined as proficiency or ability acquired or developed through training or experience, while competence can be described as an action, behaviour or outcomes which 
a person should be able to demonstrate, or the ability to transfer skills and knowledge to new situations within a given occupational area. From a semantics perspective, the term "competence" is used to define a particular knowledge or observable characteristics (Prahalad and Hamel, 1990), whereas skills are an amalgamation of human expertise and facilities, blended together by the organisation, processes, systems and culture (Klein et al., 1998). The PMI (2002) defined competence as 'a cluster of related knowledge, attitudes, skills, and other personal characteristics that affects a major part of one's job, correlates with performance on the job, can be measured against well accepted standards, can be improved via training and development and can be broken down into dimensions of competencies'. Babalola (2009) while relating this to quantity surveying profession viewed a competent quantity surveyor as a person who is expected to possess a range of skills, knowledge and understanding and be able to apply these skills and knowledge in a range of context and organization.

Quantity surveying profession is constantly confronted with challenges and opportunities in new markets. These are often passed over, predominantly because of the lack of relevant skills and competencies. These challenges and opportunities will not be fully leveraged if these skills are not addressed. Ajanlekoko (2012) emphasized the need for quantity surveyors to move away from being a 'thermometer' (reader of temperature) to being a 'thermostat' (controller of event) in the $21^{\text {st }}$ century. If this is going to be, he called for a culture change and attitudinal development of quantity surveyors.

Formal measures of skills and competences require definitions and classification of skill and competence, type and extent. However, the general literature on quantity surveying skill and competence illustrates a multiplicity of perspectives (Nkado and Meyer, 2001; Crafford and Smallwood, 2007; Babalola, 2009). A detailed review of the various classifications and definition of skill and competence reveals that they are very much at variance. There is duplication of categorizations and overlapping of definitions. Consequently, skill and competence classifications and adoptions are difficult to compare precisely because of diverse definitions.

In this paper, findings from an exploratory survey of attributes of quantity surveyors' skill and competence are reported. The focus on quantity surveyors and allied-professionals as well as clients was chosen to avoid biased perception and to embrace the view of the identified relevant stakeholders in the subject matter. The paper is structured as follows. First, a review of literature relevant to skill and competence of quantity surveyors is presented. This is followed by a description of the research method and presentation of the research findings.

\section{An Overview of Skill and Competence of Quantity Surveyors}

The RICS (1971) emphasized that the distinctive competencies or skills of the quantity surveyor are associated with measurement and valuation which provide the basis for the proper cost management of the construction project in the context of forecasting, analysing, planning, controlling and accounting. According to Leveson (1996), quantity surveying competencies lie in the financial and contractual control of the building project as well as the development of soft skills. The basic skills form the platform from which a competent quantity surveyor can develop and these are an integral part of the various units of competence. These skills may be developed during tertiary education or by personal development. Some may be included as modules of quantity surveying or construction economics courses (PAQS, 2001). For the construction professionals, there are certain basic and important skills and knowledge that are expected of them. These skills and knowledge are better learned at academic institutions and preferable, at tertiary institutions (Chan et al., 2002). In essence, they needed to be placed in a more appropriate educational framework to ensure their continuing relevance. With the recent developments in the industry and the recent

Dada, J 0 and Jagboro, G O (2012) 'Core skills requirement and competencies expected of quantity surveyors: perspectives from quantity surveyors, allied professionals and clients in Nigeria', Australasian Journal of Construction Economics and Building, 12 (4) 78-90 
explosion of information technology, the academic institutions are finding it almost impossible to disseminate all pertinent and available information and skills relevant to these professions. Alshawi et al. (2007) captioned this very well in that traditional training and education models currently in use are often criticised for the lack of coordination between the industry needs and the actual training/education delivered. This dichotomy is often characterized as 'skill and competence gaps'.

The RICS (1998) and PAQS (2001) stated the units of competencies required of quantity surveyors and described, in broad terms, the functional elements of each unit in terms of performance criteria, range indicators and evidence guide. The performance criteria specify the outcomes to demonstrate acceptable performance achieved for each element of competence. Range indicators frame the boundaries within which the performance criteria apply. Evidence guides give an indication of tangible results that confirm satisfactory demonstration of competence (Leonard, 2000). Githaiga (2004) grouped the experience of the services that quantity surveyors render into budgeting and estimating. He postulated a new role in the light of better financial management role, minimizing of risk, major savings for client and better yield on investment. Furthermore, he highlighted new areas of diversification where we have opportunity and challenges as: development appraisal, precontract cost control, taxation planning, contract administration, disputes, litigation and arbitration, technical auditing, valuation for fire insurance, fire loss adjustment, maintenance management schedule of condition and dilapidation, project management, research and development and overseas works.

The Pacific Association of Quantity Surveyors (PAQS) in response to the urgent need of quantity surveyors to reform, developed and implemented in 2001 eight basic skills requiring all quantity surveyors/cost engineers belonging to the institute in Japan, Malaysia, Singapore, Honk Kong, Australia, New Zealand, Fiji and Sri Lanka to comply with. These are: Quantification/Measurement, Communication Skills, Personal and Interpersonal Skills, Business and Management Skills, Professional Practice, Computer and Information Technology, Construction Technology, Construction Law and Regulation. This became a necessity for its members because a major component of its charter recognised that there is a world market for professional services and employment requiring the mobility of its members within the Asia-Pacific region. The PAQS was said to be equally mindful of the need to enhance its membership skills, develop new skills and encourage high standard of technical and professional skills in the international market place needed in the procurement chain world (Leonard, 2000). The RICS (1998) set out the requirements and competencies for assessment of professional competence by listing the competencies required of quantity surveyors in three categories: basic competence, core competence and optional competencies. The basic skills are common to all construction professionals under RICS structure; the core skills are uniquely required of quantity surveyors, while the optional competencies reflect areas of specialization or future career diversification (Nkado and Meyer, 2001). In the same vein, the AACE (2005) Recommended Practice 11R-88, 'Required Skills and Knowledge of Cost Engineering', presents a unique model aligned with AACE's Total Cost Management (TCM) Framework. The Framework is an annotated process map that shows how each of the skills and knowledge areas of cost engineering are applied over the life cycle of assets and projects.

Educational and training, ensuring enhancement of skills and knowledge and continuous professional development has been recognised by AIQS (2004) as factors keying to the development of quantity surveying profession. The expected competencies may be acquired by individual quantity surveyors over a lifetime of professional practice, education and training but most quantity surveyors should have attained the competencies listed as 'core' or essential, either after graduation from their tertiary course and in their first five to ten years of on the job training. A number of the other competencies are quite specialized and therefore

Dada, J 0 and Jagboro, G 0 (2012) 'Core skills requirement and competencies expected of quantity surveyors: perspectives from quantity surveyors, allied professionals and clients in Nigeria', Australasian Journal of Construction Economics and Building, 12 (4) 78-90 
optional and might only be acquired by quantity surveyors working in a specific area or on particular projects. It is therefore unlikely that all these competencies will be found in any one quantity surveyor. However, in many quantity surveying practices, the balance of these competencies is likely to be provided by pooling all the skills of the various staff (PAQS, 2001).

\section{Review of Empirical Researches on Quantity Surveyors' Skill and Competence}

There have been a number of research studies in the area of quantity surveyor's skill and competencies. Hiew and $\mathrm{Ng}$ (2007) revisited the quantity surveyors basic functions. Their study was based on how these functions can be improved upon in order to reinforce their basic values and then deals with other services. By this more values can be created for the benefit of clients. Babalola (2009) examined the core competencies of quantity surveyors in cost management and administration of electrical engineering services. This study revealed the relevant competencies expected of quantity surveyors and categorized them into strengths, weaknesses, opportunities and threats. However, the findings are limited to electrical services, which are considered a small aspect of the gamut of activities in quantity surveying practices. Therefore, this cannot give a good yardstick for listing quantity surveyors' core competencies.

Nkado and Meyer (2001), in their study, carried out a survey of quantity surveyors' professional practice in South Africa and provided a relative importance of skills and competencies required for quantity surveying services. The results from the study indicated that technically oriented competencies were rated highest. The profession was rated as deploying below average proficiency levels in marketing, advanced financial management, leadership and project management. As good as the findings of this study would have been, the respondents were limited to quantity surveyors. This can be argued as self disclosure. As such the perception of other stakeholders - clients and other built environment professionals - will be a good complement to their findings. In an attempt to fill this gap, Crafford and Smallwood (2007) based their study of quantity surveyors' competence on client perception. This study is also faulted in that; client's perception only may not give the best assessment of quantity surveyors' competence. This dichotomy between the self perception and the way other stakeholders, in the construction industry, view quantity surveyors' competence is set to be bridged in this research.

\section{Research Methodology}

This research investigated the core skills requirement and competencies expected of quantity surveyors in Nigeria. A survey method was used in eliciting necessary data for the study. Secondary data were obtained through a literature review of relevant publications and information sourced from libraries and internet. This plays a major role in the establishment of the criteria and theories against which the empirical research were measured and in the compilation of the questionnaire for the survey. Two sets of structured questionnaire were prepared; one was used for the construction professionals and the other for the clients. Generally, the first part of the questionnaire elicited general information about the respondents, including respondents' designation, years of experience, academic and professional qualifications, and their organisations. Other parts dealt with issues relating to quantity surveyors' skills and competencies. The respondents' choices of answers ranged on a 5- point Likert scale from least favourable to most favourable. Prior to sending out the final draft of the questionnaire to respondents, it was pre-tested to ensure the appropriateness of the questions in terms of rhetoric and understanding of meanings.

The study population within the context of the study is a database of relevant stakeholders in the Nigerian construction industry. The first group was the professional quantity surveyors. The second group comprised the allied professionals and for this group, the views of architects, structural engineers and builders, who were found to have direct dealings with quantity surveyors on construction projects, were obtained. The last group was the client

Dada, J 0 and Jagboro, G O (2012) 'Core skills requirement and competencies expected of quantity surveyors: perspectives from quantity surveyors, allied professionals and clients in Nigeria', Australasian Journal of Construction Economics and Building, 12 (4) 78-90 
organizations who benefits mostly from the services of quantity surveyors. Stratified and random sampling techniques were adopted in the selection of the respondents. In order to determine a suitable sample size for the professionals, the total population was obtained from the list of registered professionals published by the respective professional bodies. In selecting appropriate sample size from the lists, the Mendenhall et al. (1971) formula for calculating sample size was used. Currently the total number of registered quantity surveyors, architects, engineers and builders in the study area is 719, 672, 487 and 379 respectively. Substituting these values into the formula gives 257 quantity surveyors, 251 architects, 220 engineers and 195 builders. Random sampling method was thereafter used in selecting the respective numbers. For the client organisations, there is no published list that can be employed. Thus, it was not possible to have an exact sampling frame. As such, purposive sampling method was used in obtaining a sample size of 100 public and private client organisations.

\section{Data Analysis}

Before carrying out the data analysis, a reliability test was carried out to ensure that it was worthwhile to go ahead. The data were subjected to the Cronbach alpha reliability test. The results were greater than the Nunnally (1978) guideline, which suggested a measure of reliability of 0.70 or higher in the early stage of research predictor test. Two separate statistical analyses were thereafter undertaken using the Statistical Packages for Social Science (SPSS). The first analysis ranked the variables, based on the mean value responses, and compares the mean from the different groups (quantity surveyors, architects, builders, engineers and clients) and presented associated analysis of variance (ANOVA) for each variable within a series of quantity surveyor's skill and competence attributes.

\section{Results and Discussion}

\section{Respondents' Information}

The participants' organisations are diverse; most of them $(41.12 \%)$ are from contracting firms, $23.82 \%$ are from consulting firm while $19.33 \%$ are from government establishments. About twelve percent of the respondents are client from private establishment while $4.04 \%$ are client from public establishment. The diversity in the respondents' organisations afforded the issues, addressed in the survey, to be viewed from different perspective of construction sector.

Among the respondents, $31.91 \%$ are quantity surveyors, $18.20 \%$ are builders, $17.98 \%$ are engineers while $16.18 \%$ are architects. The remaining $15.70 \%$ are from client organisations and the respondents range from accountants $(3.60 \%)$, lawyers $(1.80 \%)$, insurance brokers $(0.67 \%)$, medical doctors $(1.12 \%)$, bankers $(2.25 \%)$ and estate surveyors (1.57\%). Among the respondents from client organizations, their status range from managing director/chief executive officer, general manager, director, project manager and head of department among others. Furthermore, $21.35 \%$ and $20.67 \%$ of the respondents have M.Sc. and MBA respectively. About $4 \%$ have Ph.D. while $22.92 \%$ and $19.55 \%$ have B.Sc. and HND respectively as their highest academic qualifications. About $69 \%$ of the respondents are professionals who are associate members of their respective professional bodies. In addition, $12.80 \%$ are fellows of their professional bodies while the average years of experience of the respondents stand at 15.

From the general background information results, it seems plausible to contend that the respondents, who participated in the survey, are adjudged to be of good academic and professional background. This should give credibility to the data collected.

\section{Skills Required of Quantity Surveyors}

The survey results on the skills required of quantity surveyors are shown in Table 1. For the 21 identified skills variables, the mean values have wide range spectrum, from the lowest

Dada, J 0 and Jagboro, G O (2012) 'Core skills requirement and competencies expected of quantity surveyors: perspectives from quantity surveyors, allied professionals and clients in Nigeria', Australasian Journal of Construction Economics and Building, 12 (4) 78-90 
value of 2.60 (solid mineral engineering) to the highest value of 3.59 (computer literacy). Fifteen (15), of the items, are considered important by the respondents while the remaining 6 are considered fairly important. The important skills are: computer literacy (mean value of 3.59); building engineering (3.34); information technology (3.33); economics (3.27); and measurement/quantification (3.23).

Considering the rating of computer literacy and information technology; it was considered appropriate. This is consistent with Nkado and Meyer (2001) survey, which identifies 'computer literacy and information technology' as the most important skill required of quantity surveyors. This is also in line with the findings of Humphery and Stokes (2000) and White and Fortune (2002) studies where it was suggested that computer can help a project manager to be more efficient at their job. In fact, 75 percent of Humphery and Stokes' respondents indicated the ability to use computers as being one of the most important set of skills for a project manager to possess. This also supports the findings of Musa et al. (2010), that computer literacy and information technology skills will play a major role in the activities of the quantity surveyors in the future. Any quantity surveyor attempting to compete and succeed without these modern tools will be handicapped and their risk of failure will increase.

One notable outcome is that the routine technical skill of measurement/quantification was rated lower than computer literacy and information technology skill. This suggests that enhanced computer literacy and information technology skills will be an added advantage in the discharge of basic technical competence such as measurement and quantification. Presently, efforts are being shifted to automation in doing things generally. Some services have diminished considerably or are being automated by technology. The reality is that whatever can be done manually can be automated. The benefit of this cannot be overemphasized in terms of time saving, accuracy and productivity.

Building engineering, which relates to building construction knowledge, is also rated high. The implication of this is that quantity surveyors need adequate knowledge of building construction before they carry out their basic duty of quantification and cost management of construction works. Another important skill is the knowledge of economics. Economics deals with the study of forces affecting the use of scarce or limited resources in satisfying human needs. The application of this to construction seeks to ensure the efficient use of the available resources in the most efficient manner. This is considered very important to quantity surveying profession in cost planning and management of construction works. The result is therefore considered appropriate.

Other important skills are: knowledge of civil/heavy engineering (with a mean value of 3.16); professional practice (3.15); construction law (3.14); interpersonal skill (3.11); knowledge of mechanical and electrical services engineering (3.10); financial skill (3.94) and leadership skill (3.09). The implication of this result is that, appropriate engineering technology is of paramount important and basic thing a quantity surveyor must acquire. This will help a lot in the measurement and quantification of different categories of construction works. The issue of professional practice is also considered important. This can be regarded as non negotiable, as it forms the summary of what a quantity surveyor does. Interpersonal skill is also seen to be important. This is evidence from the fact that the barriers between professions are being broken down as they seek to survive in an increasingly complex and competitive society. Hoxley et al. (2007) suggested that successful architectural practices should be able to successfully articulate a clear competence to potential clients and to have a clear view of the particular market segment that they serve. In line with this, quantity surveying practice can be competitively differentiated by acquisition of basic skill of design principles, engineering and the use of information technology.

Dada, J 0 and Jagboro, G O (2012) 'Core skills requirement and competencies expected of quantity surveyors: perspectives from quantity surveyors, allied professionals and clients in Nigeria', Australasian Journal of Construction Economics and Building, 12 (4) 78-90 
Australasian Journal of Construction Economics and Building

\begin{tabular}{|c|c|c|c|c|c|c|c|c|c|c|c|c|c|c|}
\hline \multirow{2}{*}{ Skill } & \multicolumn{2}{|c|}{ QS } & \multicolumn{2}{|c|}{ Architect } & \multicolumn{2}{|c|}{ Engineer } & \multicolumn{2}{|c|}{ Builder } & \multicolumn{2}{|c|}{ Client } & \multicolumn{2}{|c|}{ Overall } & \multirow{2}{*}{$\mathbf{F}$} & \multirow{2}{*}{ Sig. } \\
\hline & Mean & Rk. & Mean & Rk. & Mean & Rk. & Mean & Rk. & Mean & Rk. & Mean & Rk. & & \\
\hline Computer Literacy & 3.63 & 1 & 3.55 & 1 & 3.52 & 1 & 3.57 & 1 & 3.65 & 1 & 3.59 & 1 & 0.582 & 0.676 \\
\hline Building Engineering & 3.36 & 2 & 3.18 & 3 & 3.38 & 3 & 3.35 & 3 & 3.43 & 2 & 3.34 & 2 & 0.968 & 0.425 \\
\hline Information Technology & 3.34 & 3 & 3.31 & 2 & 3.24 & 5 & 3.32 & 4 & 3.41 & 4 & 3.33 & 3 & 0.475 & 0.754 \\
\hline Economics & 3.33 & 4 & 3.04 & 6 & 3.08 & 9 & 3.42 & 2 & 3.43 & 2 & 3.27 & 4 & 3.293 & $0.011^{*}$ \\
\hline Measurement/Quantification & 3.20 & 7 & 3.14 & 4 & 3.41 & 2 & 3.11 & 10 & 3.00 & 18 & 3.23 & 5 & 2.996 & $0.019^{*}$ \\
\hline Civil/Heavy Engineering & 3.28 & 5 & 2.90 & 14 & 3.04 & 11 & 3.15 & 7 & 3.33 & 8 & 3.16 & 6 & 3.772 & $0.005^{*}$ \\
\hline Professional Practice & 3.11 & 11 & 2.96 & 7 & 3.28 & 4 & 3.26 & 5 & 3.12 & 15 & 3.15 & 7 & 1.393 & 0.236 \\
\hline Construction Law & 3.18 & 8 & 2.94 & 8 & 3.08 & 9 & 3.15 & 7 & 3.35 & 7 & 3.14 & 8 & 1.719 & 0.145 \\
\hline Interpersonal Skill & 3.12 & 9 & 2.93 & 13 & 3.13 & 6 & 3.10 & 13 & 3.29 & 9 & 3.11 & 9 & 1.410 & 0.230 \\
\hline M\&E Services Engineering & 3.22 & 6 & 2.94 & 8 & 2.84 & 15 & 3.12 & 9 & 3.28 & 10 & 3.10 & 10 & 3.786 & $0.005^{*}$ \\
\hline Financial skills & 3.12 & 9 & 2.94 & 8 & 3.01 & 12 & 3.18 & 6 & 3.23 & 11 & 3.10 & 10 & 1.250 & 0.289 \\
\hline Leadership skills & 3.06 & 13 & 2.94 & 8 & 3.01 & 12 & 3.09 & 14 & 3.37 & 6 & 3.09 & 12 & 2.400 & $0.049^{*}$ \\
\hline Managerial skill & 3.06 & 13 & 2.94 & 8 & 3.10 & 8 & 3.05 & 15 & 3.21 & 12 & 3.07 & 13 & 0.848 & 0.495 \\
\hline Communication skill & 3.01 & 15 & 3.09 & 5 & 3.13 & 6 & 3.11 & 10 & 3.09 & 15 & 3.07 & 13 & 0.299 & 0.878 \\
\hline Marketing/Business skill & 3.07 & 12 & 2.86 & 15 & 2.72 & 17 & 3.02 & 16 & 3.40 & 5 & 3.01 & 15 & 4.984 & $0.001^{*}$ \\
\hline Mapping/Surveying & 2.96 & 17 & 2.70 & 16 & 2.95 & 14 & 2.99 & 17 & 3.17 & 14 & 2.96 & 16 & 2.028 & 0.090 \\
\hline Actuarial skill(Knowledge about insurance) & 2.89 & 18 & 2.57 & 17 & 2.73 & 16 & 3.11 & 10 & 3.20 & 13 & 2.90 & 17 & 4.931 & $0.001^{*}$ \\
\hline Gas and petrochemical engineering & 2.96 & 16 & 2.51 & 18 & 2.38 & 21 & 2.72 & 20 & 3.09 & 16 & 2.76 & 18 & 7.668 & $0.000^{*}$ \\
\hline Knowledge about International Trading & 2.78 & 19 & 2.43 & 19 & 2.54 & 18 & 2.79 & 19 & 2.94 & 20 & 2.71 & 19 & 2.698 & $0.030^{*}$ \\
\hline Investment Analysis & 2.68 & 21 & 2.32 & 20 & 2.52 & 19 & 2.80 & 18 & 2.74 & 21 & 2.62 & 20 & 2.256 & 0.062 \\
\hline Solid Mineral Engineering & 2.76 & 20 & 2.19 & 21 & 2.40 & 20 & 2.64 & 21 & 2.91 & 19 & 2.60 & 21 & 5.554 & $0.000^{*}$ \\
\hline
\end{tabular}

* significant at $5 \%$ level

Table 1 Skills required of Quantity Surveyors

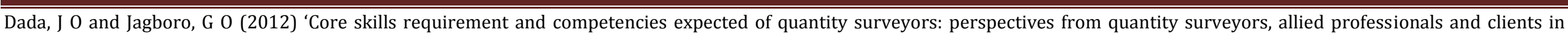
Nigeria', Australasian Journal of Construction Economics and Building, 12 (4) 78-90 
Skills such as communication, managerial and marketing/business attract a moderate mean rating of 3.09, 3.07 and 3.01 respectively. These are considered basic skills necessary in addition to the technical skills. Quantity surveying graduates have to be equipped not only with the technical knowledge but also in communicating and dealing with people. Other skills, which were considered fairly important, are: mapping/surveying (2.96), actuarial science (knowledge about insurance (2.90); and gas/petrochemical engineering (2.76).

Knowledge about international trading, investment analysis and solid mineral engineering were rated least. Their respective means are 2.71, 2.62 and 2.60. The implication of this is that these skills are considered less important for quantity surveyors. They can be categorized as future areas or skills to be explored. The ANOVA conducted on the results (at Sig. $<5 \%$ ) showed difference in the opinion among the groups of respondents in 10 items. These are: Civil/Heavy Engineering, Gas/Petrochemical Engineering, Solid mineral Engineering, Measurement/Quantification, Economics, Marketing/Business Skill and Leadership Skill. Others are, Actuarial Skill and knowledge about International Trading. This may be due to the fact that some of the respondents might think that anything that have to do with engineering and business skill may not be necessary for quantity surveyors. The results of the overall mean ranking, however, proved otherwise this assumed notion.

\section{Classification of Skills Required of Quantity Surveyors}

This section reports on the results of classification of the identified skills required of quantity surveyors. The detailed survey results are shown in Table 2, in which the preferred classifications are presented in percentages. Two main classifications were identified: basic and core skill classifications. The basic skills are those common and required of all construction professions, while the core skills are those uniquely required of quantity surveyors. The principle of classification is based on majority opinion $(50 \%)$. If over $50 \%$ of the respondents are in favour of basic classification, then the particular skill is classified as 'basic skill'. A similar principle is applied to 'core skill' classification.

\begin{tabular}{|l|c|c|c|c|c|}
\hline \multicolumn{1}{|c|}{ Skill } & $\begin{array}{c}\text { Mean } \\
\text { Ranking }\end{array}$ & Rank & Basic & Core & $\begin{array}{c}\text { Preferred } \\
\text { Classification }\end{array}$ \\
\hline Computer literacy & 3.59 & 1 & $45.2 \%$ & $54.8 \%$ & Core \\
\hline Building Engineering & 3.34 & 2 & $40.4 \%$ & $59.6 \%$ & Core \\
\hline Information Technology & 3.33 & 3 & $64.5 \%$ & $35.5 \%$ & Basic \\
Economics & 3.27 & 4 & $42.7 \%$ & $57.3 \%$ & Basic \\
Measurement/Quantification & 3.23 & 5 & $39.8 \%$ & $60.2 \%$ & Core \\
Civil/Heavy Engineering & 3.16 & 6 & $57.6 \%$ & $42.4 \%$ & Basic \\
\hline Professional Practice & 3.15 & 7 & $30.1 \%$ & $69.9 \%$ & Core \\
Construction Law & 3.14 & 8 & $40.9 \%$ & $59.1 \%$ & Core \\
Interpersonal Skill & 3.11 & 9 & $59.8 \%$ & $40.2 \%$ & Basic \\
M \& E service Engineering & 3.10 & 10 & $64.5 \%$ & $35.5 \%$ & Basic \\
\hline Financial skill & 3.10 & 10 & $38.9 \%$ & $61.1 \%$ & Core \\
\hline Leadership skill & 3.09 & 12 & $63.9 \%$ & $36.2 \%$ & Basic \\
Managerial Skill & 3.07 & 13 & $60.7 \%$ & $39.3 \%$ & Basic \\
Communication skill & 3.07 & 13 & $57.7 \%$ & $42.2 \%$ & Basic \\
\hline Marketing/Business Skill & 3.01 & 15 & $58 \%$ & $42.0 \%$ & Basic \\
Mapping/Surveying & 2.96 & 16 & $59.3 \%$ & $40.7 \%$ & Basic \\
\hline Actuarial skill (knowledge about insurance) & 2.90 & 17 & $59.6 \%$ & $40.4 \%$ & Basic \\
Gas and Petrochemical Engineering & 2.76 & 18 & $73 \%$ & $27.0 \%$ & Basic \\
\hline Knowledge about International Trading & 2.71 & 19 & $69.7 \%$ & $30.3 \%$ & Basic \\
Investment analysis & 2.62 & 20 & $77.5 \%$ & $22.5 \%$ & Basic \\
\hline Solid mineral Engineering & 2.60 & 21 & $72.6 \%$ & $27.4 \%$ & Basic \\
\hline
\end{tabular}

Table 2 Classification of Skills Required of Quantity Surveyors

There are fourteen skills preferred to be classified as 'basic'. They are: information technology, civil/heavy engineering, mechanical and electrical services engineering, gas and

Dada, J 0 and Jagboro, G O (2012) 'Core skills requirement and competencies expected of quantity surveyors: perspectives from quantity surveyors, allied professionals and clients in Nigeria', Australasian Journal of Construction Economics and Building, 12 (4) 78-90 
petrochemical engineering, solid mineral engineering, marketing/business skills, leadership skills, managerial skills, interpersonal skills and communication skills. Others are: actuarial skills, knowledge about international trading and investment analysis. These are all regarded as essential requirements needed by quantity surveyors to be able to perform his duty. They can also be regarded as essential supporting skills.

Core skills are shown as: computer literacy, building engineering, measurement/quantification, economics, construction law, professional practice and financial skills. These are regarded as core skills germane to the common duty of quantity surveyors.

\section{Competencies Expected of Quantity Surveyors}

As indicated in the literature review section, competence was broadly summarized as actions which are observable in the execution of one's work. In other words, it is regarded as the applied skill and knowledge that enable people to perform specified functions or works. The expected competencies of quantity surveyors therefore lie in the outcome and display of the various acquired skills. The survey results on this are as indicated in Table 3.

The mean values range from the lowest value of 2.94 to the highest value of 3.65 . From the results, cost planning and control (with a mean value of 3.65); estimating (3.63); construction procurement system (3.56); contract documentation (3.52); contract administration (3.43); project management (3.37); feasibility/viability studies (3.33); valuation (3.29); financial management (3.26); development economics (3.11) and risk management (3.09) constitutes those competencies rated important. The listing of cost planning and control as the most important competence may not be out of place. The summary of what a quantity surveyor does lie in the financial and contractual control of building project. It should be noted that budgeting for capital projects implies a dynamic process incorporating both planning and control systems enabling corrective actions when necessary. The business of cost planning of 'designs' at the design stage and the appropriate application of cost control methodologies and techniques at the construction stage is therefore very crucial to the fulfillment of this basic duty of a quantity surveyor in any construction project.

Furthermore, estimating, project procurement, contract documentation and administration all constitute the core technical services provided by quantity surveyors. It is therefore not surprising that these items were rated very important. These results compares favourably with the APC standard sets by the RICS. The RICS (1998) authoritatively set out the core competence of quantity surveyors as, procurement and financial management, economics of construction, construction contract and practice and construction technology and environmental services.

Other competence areas rated important are: life cycle costing (3.05), facility management (3.03). Arbitration and dispute resolution (2.99) and economic management of urban infrastructure (2.94) were rated low. The indicated low ratings of these competencies may suggest a general dissatisfaction of the quality of professional services offered in these areas. They can also be considered as areas where quantity surveyors' services are not pronounced. As such they are adjudged areas to be intensified and/or incorporated in quantity surveying training.

The respondents (groups) held different opinions on six out of the fifteen items listed at $5 \%$ significant level. These are feasibility/viability studies, development economics, cost planning and control, construction procurement system, facility management, and arbitration and dispute resolution.

Dada, J 0 and Jagboro, G O (2012) 'Core skills requirement and competencies expected of quantity surveyors: perspectives from quantity surveyors, allied professionals and clients in Nigeria', Australasian Journal of Construction Economics and Building, 12 (4) 78-90 


\begin{tabular}{|c|c|c|c|c|c|c|c|c|c|c|c|c|c|c|}
\hline \multirow{2}{*}{ Competence } & \multicolumn{2}{|c|}{ QS } & \multicolumn{2}{|c|}{ Architect } & \multicolumn{2}{|c|}{ Engineer } & \multicolumn{2}{|c|}{ Builder } & \multicolumn{2}{|l|}{ Client } & \multicolumn{2}{|l|}{ Overall } & \multirow{2}{*}{$\mathbf{F}$} & \multirow{2}{*}{ Sig. } \\
\hline & Mean & Rk. & Mean & Rk. & Mean & Rk. & Mean & Rk. & Mean & Rk. & Mean & Rk. & & \\
\hline Cost Planning and Control & 3.69 & 1 & 3.41 & 2 & 3.72 & 2 & 3.78 & 1 & 3.60 & 2 & 3.65 & 1 & 3.182 & $0.014^{*}$ \\
\hline Estimating & 3.64 & 2 & 3.46 & 1 & 3.75 & 1 & 3.75 & 2 & 3.53 & 3 & 3.63 & 2 & 1.864 & 0.116 \\
\hline Construction Procurement System & 3.64 & 2 & 3.36 & 3 & 3.40 & 4 & 3.67 & 4 & 3.66 & 1 & 3.56 & 3 & 3.432 & $0.009^{*}$ \\
\hline Contract Documentation & 3.60 & 4 & 3.32 & 4 & 3.43 & 3 & 3.70 & 3 & 3.46 & 4 & 3.52 & 4 & 2.187 & 0.070 \\
\hline Contract Administration & 3.58 & 5 & 3.26 & 5 & 3.25 & 7 & 3.49 & 5 & 3.40 & 5 & 3.43 & 5 & 2.032 & 0.089 \\
\hline Project Management & 3.53 & 7 & 3.19 & 6 & 3.34 & 5 & 3.34 & 7 & 3.33 & 6 & 3.37 & 6 & 2.043 & 0.087 \\
\hline Feasibility/Viability Studies & 3.45 & 6 & 3.17 & 7 & 3.20 & 8 & 3.29 & 9 & 3.28 & 10 & 3.33 & 7 & 2.500 & $0.042^{*}$ \\
\hline Valuation & 3.31 & 9 & 3.17 & 7 & 3.34 & 5 & 3.30 & 8 & 3.31 & 8 & 3.29 & 8 & 0.327 & 0.860 \\
\hline Financial Management & 3.32 & 8 & 3.04 & 10 & 3.18 & 9 & 3.42 & 6 & 3.26 & 11 & 3.26 & 9 & 1.855 & 0.117 \\
\hline Development Economics & 3.30 & 10 & 2.80 & 14 & 2.84 & 13 & 3.26 & 10 & 3.19 & 12 & 3.11 & 10 & 6.207 & $0.000^{*}$ \\
\hline Risk Management & 3.15 & 11 & 3.06 & 9 & 2.92 & 11 & 2.99 & 14 & 3.33 & 6 & 3.09 & 11 & 1.825 & 0.123 \\
\hline Life Cycle Costing & 3.13 & 12 & 3.00 & 12 & 2.91 & 12 & 3.12 & 12 & 3.04 & 13 & 3.05 & 12 & 0.650 & 0.627 \\
\hline Facility Management & 3.12 & 13 & 2.88 & 13 & 2.76 & 14 & 3.05 & 13 & 3.29 & 9 & 3.03 & 13 & 3.521 & $0.008^{*}$ \\
\hline Arbitration and Dispute Resolution & 3.10 & 14 & 3.04 & 10 & 2.62 & 15 & 3.18 & 11 & 2.93 & 15 & 2.99 & 14 & 4.016 & $0.003^{*}$ \\
\hline Economic Mgmt. of Urban Infrastructure & 3.04 & 15 & 2.69 & 15 & 2.99 & 10 & 2.89 & 15 & 3.00 & 14 & 2.94 & 1 & 2.137 & 0.075 \\
\hline
\end{tabular}

* significant at $5 \%$ level

Table 3 Competencies Expected of Quantity Surveyor

Dada, J O and Jagboro, G O (2012) 'Core skills requirement and competencies expected of quantity surveyors: perspectives from quantity surveyors, allied professionals and clients in Nigeria', Australasian Journal of Construction Economics and Building, 12 (4) 78-90 


\section{Classification of Competencies Expected of Quantity Surveyors}

This section reports on the results of classification of the competencies expected of quantity surveyors. The detailed survey results are shown in Table 4, in which the preferred classifications are presented in percentages. Three main classifications are identified: core, optional and special competence classifications. The core competencies are those common and germane to day to day activities of quantity surveyors. The optional competencies reflect the area of specialization, while the special ones can be regarded as those required for future career diversifications. The principle of classification is based on majority opinion. If over $50 \%$ of the respondents are in favour of core classification, then the particular competence is classified as 'core'. A similar principle is applied to 'optional' and 'special' classification. However, where none of the option is over $50 \%$, the particular competence is regarded has being classified as the option with the highest percentage.

\begin{tabular}{|l|c|c|c|c|c|c|}
\hline \multicolumn{1}{|c|}{ Competence } & $\begin{array}{c}\text { Mean } \\
\text { Ranking }\end{array}$ & Rank & Core & Optional & Special & $\begin{array}{c}\text { Preferred } \\
\text { Classification }\end{array}$ \\
\hline Cost Planning and Control & 3.65 & 1 & $83.0 \%$ & $8.5 \%$ & $8.5 \%$ & Core \\
\hline Estimating & 3.63 & 2 & $79.7 \%$ & $7.6 \%$ & $12.6 \%$ & Core \\
\hline Construction Procurement System & 3.56 & 3 & $71.2 \%$ & $13.5 \%$ & $15.3 \%$ & Core \\
\hline Contract Documentation & 3.52 & 4 & $74.2 \%$ & $16.4 \%$ & $9.4 \%$ & Core \\
\hline Contract Administration & 3.43 & 5 & $69.2 \%$ & $15.5 \%$ & $15.3 \%$ & Core \\
\hline Project Management & 3.37 & 6 & $61.5 \%$ & $23.4 \%$ & $15.1 \%$ & Core \\
\hline Feasibility/Viability Studies & 3.33 & 7 & $63.4 \%$ & $24.9 \%$ & $11.7 \%$ & Core \\
\hline Valuation & 3.29 & 8 & $59.1 \%$ & $25.4 \%$ & $15.5 \%$ & Core \\
\hline Financial Management & 3.26 & 9 & $56.2 \%$ & $28.1 \%$ & $15.7 \%$ & Core \\
\hline Development Economics & 3.11 & 10 & $57.9 \%$ & $31.5 \%$ & $10.6 \%$ & Core \\
\hline Risk Management & 3.09 & 11 & $18.9 \%$ & $28.3 \%$ & $52.8 \%$ & Special \\
\hline Life Cycle Costing & 3.05 & 12 & $51.2 \%$ & $22.7 \%$ & $26.1 \%$ & $\begin{array}{c}\text { Core } \\
\text { Facility Management }\end{array}$ \\
\hline Arbitration and Dispute Resolution & 3.03 & 13 & $18.2 \%$ & $28.3 \%$ & $52.8 \%$ & Special \\
\hline Economic Mgmt. of Urban Infrastructure & 2.99 & 14 & $51.9 \%$ & $25.6 \%$ & $22.5 \%$ & Core \\
\hline
\end{tabular}

Table 4 Classification of Competencies Expected of Quantity Surveyors

From the results, the core competencies are presented as: feasibility/viability studies, development economics, cost planning and control, estimating, construction procurement system, contract documentation, contract administration, project management, financial management, valuation, life cycle costing and arbitration/dispute resolutions. Facility and risk management are classified as special competencies while the only competence listed as optional is economic management of urban infrastructure.

\section{Conclusions and Recommendations}

Based on the explorative survey of major stakeholders in the Nigerian construction industry, this paper presents the findings of a study that examined the core skill requirement and competencies expected of quantity surveyors. Among the twenty one skills variables investigated, the survey showed fifteen of them as important. These are: computer literacy, building engineering, information technology, economics, measurement/quantification, knowledge of civil/heavy engineering, professional practice, construction law, interpersonal skill, knowledge of mechanical and electrical services engineering, financial skill and leadership skill, communication skill, managerial skill and marketing/business skill. Further analysis was used in categorizing the skills to basic and core skills. The result presents the basic skills as information technology, civil/heavy engineering, mechanical and electrical

Dada, J 0 and Jagboro, G O (2012) 'Core skills requirement and competencies expected of quantity surveyors: perspectives from quantity surveyors, allied professionals and clients in Nigeria', Australasian Journal of Construction Economics and Building, 12 (4) 78-90 
services engineering, gas and petrochemical engineering, solid mineral engineering, marketing/business skill, leadership skill, managerial skill, interpersonal skill, and communication skill, actuarial skill, knowledge about international trading and investment analysis. The core skills were shown as computer literacy, building engineering, measurement/quantification, economics, construction law, professional practice and financial skill.

Considering the competencies expected of quantity surveyors; the research showed the important variables as: cost planning and control, estimating, construction procurement system, contract documentation, contract administration, project management, feasibility and viability studies, valuation, financial management, development economics, risk management, life cycle costing, facility management and arbitration/dispute resolution. The results of further analysis presents the core competencies as: feasibility/viability studies, development economics, cost planning and control, estimating, construction procurement system, contract documentation, contract administration, project management, financial management, valuation, life cycle costing and arbitration/dispute resolutions. Facility and risk management are classified as special competencies while economic management of urban infrastructure is classified as optional competence.

The study has provided considerable insight into the issue of quantity surveyors' skill and competence. The findings of this research have considerable implications on the training and practice of quantity surveyors. These implications affect most players in quantity surveying training and practice: the academic institutions, the practitioners, the user of quantity surveying services and the professional bodies responsible for the regulation of quantity surveying practice in Nigeria.

From the outcome of the study, the following recommendations are made. Firstly, the important skills and competencies identified in the survey should be given prominence, in the training and continuous development of the quantity surveying profession. Secondly, the academic institutions and the National University Commission in collaboration with the NIQS should critically address this during accreditation and in running quantity surveying programs in Nigerian higher institutions. Finally, the NIQS and QSRBN should endeavour to make strong representation in the review of quantity surveying academic program to reflect the important skills and competencies which are lacking in the current program. This will not only enrich quantity surveying curriculum and make it meet the current need of the industry but will make Nigerian quantity surveyors marketable in the global market.

\section{References}

AACE (2005) Recommended Practice 11R-88, Required Skills and Knowledge of Cost Engineering, Morgantown, WV: AACE International

Ajanlekoko, J.O. (2012) 'From Thermometer to Thermostat: The challenging role for the Quantity Surveyors in the $21^{\text {st }}$ Century', The Quantity Surveyor: Journal of the Nigerian Institute of Quantity Surveyors, 1 (1), 40-41

Alshawi, M., Goulding, J. and Nadim, W. (2007) Training and Education for Open Building Manufacturing: Closing the Skills Gap Paradigm, In: Kazi, A.S., Hannus, M., Boudjabeur, S. and Malone, A. (eds.) Open Building Manufacturing: Core Concepts and Industrial Requirements. Finland, 191-214

AIQS (2004) World's Best Practice in Quantity Surveying - What it means to you, AIQS Brochure, Australia: Australian Institute of Quantity Surveyors

Babalola, O. (2009) 'A study of the core competencies of quantity surveyors in managing electrical and engineering services sub-contract', Journal of Environmental Design and Management, 2 (1), 55-64

Dada, J 0 and Jagboro, G 0 (2012) 'Core skills requirement and competencies expected of quantity surveyors: perspectives from quantity surveyors, allied professionals and clients in Nigeria', Australasian Journal of Construction Economics and Building, 12 (4) 78-90 
Chan, E.W.H., Chan, M.W., Scott, D. and Chan, A.T.S. (2002) 'Educating the $21^{\text {st }}$ century professionals', Journal of Professional Issues in Engineering Education and Practices, January, 44-51

Crafford, G.J. and Smallwood, J.J. (2007) 'Clients' views on quantity surveying competencies', Acta structilia: Journal for the physical and development sciences, 14 (1), 33-55

Githaiga, F.M. (2004) 'Challenges facing the Quantity Surveying Profession in a Globalized Economy', Proceedings of the $21^{\text {st }}$ Biennial Conference of Nigerian Institute of Quantity Surveyors (NIQS): Adding Value to Reforming Challenges for the Quantity Surveying Profession in Nigeria, Premier Hotel, Ibadan, Nigeria, 24-27 November, 32-48

Hiew and $\mathrm{Ng}$ (2007) 'How the quantity surveying can create values in the procurement of construction works in Hong Kong', Proceedings of TS 5G: Affordable and Sustainable Development - Strategic Intervention of Surveying Services, FIG Working Week, Hong Kong SAR, China, 13-17 May, 57-78

Hoxley, M., Knight, A. and Grada, M. (2007) 'Construction Professional Services: A Process Model', Proceedings of RICS COBRA Research Conference, Georgia Institute of Technology, Atlanta, USA, 6-7 September, 1-8

Humphery, B. and Stokes, J. (2000) The $21^{\text {st }}$ Century Supervisors: Nine Essential Skills for Frontline Leaders, Jossey-Bass/Pfeiffer, San Francisco Califonia

Klein, J., Gee, D. and Jones, H. (1998) 'Analysing Clusters of Skill in R\&D: Core Competencies, Metaphors, Visualisation, and the Role of IT', R\&D Management Journal, 28 (1), 37-42

Leonard, D (2000) 'Future Challenges in Cost Engineering: Creating Cultural Change Through the Development of Core Competences', in 2000 AACE International Transactions, Calgary Canada, 25-28 June, 18-33

Leveson, R. (1996) 'Can professionals be multi-skilled?', People Management, 2 (17), 36-39

Mendenhall, W., Ott, L. and Scheaffer, (1971) Elementary Survey Sampling, Woodsworth Publishing Company, Belmont

Musa, N.A., Babalola, M.O. and Oyebisi, T.O (2010) 'Competencies Required of Quantity Surveying Profession in Nigeria towards achieving the Millennium Development Goals in the Built Environment', in Sustainable Environment (edited by Fadare, S.O. and Adeasanya, D.A.), Faculty of Environmental Design and Management, Obafemi Awolowo University, Ile-Ife, Nigeria, 233-244

Nkado, R. and Meyer, T. (2001) 'Competencies of professional quantity surveyors: South African perspective', Construction Management and Economics, 19, 481-491

Nunnally, J.C. (1978) Psychometric Theory (2 ${ }^{\text {nd }}$ edition), McGraw-Hill, New York

Odusami, K.T., Oyediran, O.S. and Oseni, A.O. (2007) 'Training Needs of Construction Site Managers', Emirate Journal for Engineering Research, 12 (1), 73-81

PAQS (2001) Competency Standard for Quantity Surveyors in the Asian-Pacific Region, Pacific Association of Quantity Surveyors, available at http://www.paquantitysurveyor.net, (accessed 02 December, 2011)

PMI (2002) Project Manager Competency Development Framework, Pennsylvania, Newton Square: Project Management Institute.

Prahalad, C.K. and Hamel, G. (1990) 'The Core Competence of the Corporation', Harvard Business Review, May-June, 68, 79-91

RICS (1971) The future role of Quantity Surveyors, London: Royal Institution of Chartered Surveyors

RICS (1998) The APC Requirement and Competencies, London: Royal Institution of Chartered Surveyors

White, D. and Fortune, J. (2002) 'Current practice in project management: an empirical study', International Journal of Project Management, 20 (1), 1-11

Dada, J 0 and Jagboro, G O (2012) 'Core skills requirement and competencies expected of quantity surveyors: perspectives from quantity surveyors, allied professionals and clients in Nigeria', Australasian Journal of Construction Economics and Building, 12 (4) 78-90 